\title{
PREDICTORS OF AUDIT QUALITY: AN EMPIRICAL MODEL
}

\author{
William Rudy Soegiharto', Liana Rahardja ${ }^{2 *}$, Kaswandi Zainal ${ }^{3}$, Wenny Chandra Mandagie ${ }^{4}$ \\ STIE Jakarta International College, Indonesia. \\ *Corresponding Author: liana.rahardja@jic.ac.id
}

\begin{tabular}{|c|c|}
\hline ARTICLE INFO & ABSTRACT \\
\hline $\begin{array}{l}\text { Article History: } \\
\text { Received: February 07, } 2020 \\
\text { Revised: July 08, 2020 } \\
\text { Published Online: August 17, } 2020 \\
\text { Keywords: } \\
\text { Auditors' Independency, Work } \\
\text { Experience, Professional Competence, } \\
\text { Accountability, Audit Quality. } \\
\text { How to cite: } \\
\text { Soegiharto, W. R., Rahardja, L., } \\
\text { Zainal, K., Mandagie, W. C. (2020). } \\
\text { Predictors of Audit Quality: An } \\
\text { Empirical Model. International } \\
\text { Journal of Digital Entrepreneurship } \\
\text { and Business (IDEB), 1(1), 11 - 22. }\end{array}$ & $\begin{array}{l}\text { This study aims to determine the relationship of auditor's independency, } \\
\text { work experience, professional competence and audit accountability on } \\
\text { audit quality through a survey conducted in five branches of the Public } \\
\text { Accountant Firm Doli, Bambang, Sulistiyanto, Dadang \& Ali (CPA FIRM } \\
\text { DBSDA), based in Bandung, Malang, Central Jakarta, West Jakarta and } \\
\text { South Jakarta. The population is permanent employees who have worked } \\
\text { for at least one year in five DBSDA CPA FIRM branches and have } \\
\text { completed a Bachelor of Education. The research sample consisted of } 38 \\
\text { employees who responded to the distributed questionnaire. The results } \\
\text { showed that independence, work experience, professional competence } \\
\text { and audit accountability have a positive influence on audit quality. } \\
\text { Through the partial testing, we find that auditors' independency, work } \\
\text { experience, professional competency, and accountability have a positive } \\
\text { effect on audit quality. The practical implications of the results of the } \\
\text { study are: (1) audit work is to be carried out by experienced auditors who } \\
\text { have adequate knowledge, (2) senior auditors need to supervise junior } \\
\text { auditors in conducting audits and examine work performed by junior } \\
\text { auditors, and (3) auditors need to maintain auditor independence to ensure } \\
\text { that auditor independence is not influenced by the client. }\end{array}$ \\
\hline
\end{tabular}

\section{INTRODUCTION}

The Public Accounting Firm (CPA Firm) provides a variety of services such as taxation, management consulting and accounting and management services (Arens, Elder \& Beasley, 2011). In addition to these non-assurance services, the CPA Firm also provides audit services such as assurance services. In Indonesia, regulations regarding audit services are contained in Law Number 5 of 2011. In article 3 of Law 5 2011, "Public Accountants can provide assurance services which include audit services on historical reports". According to Audit Standard (SA) 200, there are two main objectives of the auditor: (1) Provide a guarantee whether the financial statements as a whole are free from material false statements, whether through embezzlement or error, so that the auditor can provide an opinion whether the financial statements are prepared according to the applicable framework; (2) Report financial reports and communicate as requested by the International Standards on Auditing. Of the two objectives, it is clear that the auditor has a very important role to provide financial statement guarantees. Many related parties will rely on audit reports to provide assurance that the company has been honest in reporting their financial results. Ardani (2017) writes that the use of an independent auditor as a third party in examining and issuing opinions on financial statements makes the audit results trustworthy by interested parties.

The auditor also has only limited time to provide audit reports. Financial Services Authority (Otoritas Jasa Keuangan/OJK) Regulation No.29/POJK.04/2016 concerning the issuer's financial statements only provide a period of 4 months from the date of completion of the financial year to the time of the audited financial statements to be given to the Financial Services Authority. Within this time period, the auditor needs to complete all relevant work papers and provide an opinion on the financial statements. The 
public accounting Firm client wants the audit report to be completed in the shortest time possible. Timely audited financial statements can have a variety of effects on the company. Chambers and Penman (1984) stated that late earnings announcements can cause abnormal returns while faster earnings announcements show the opposite results. The result of abnormal returns is that the information has not been given a price by the market so that investors are more afraid to invest in the company. Thus, the company wants to clean up the audited financial statements as soon as possible so that they can use the financial statements for various things such as requesting a bank loan.

Given that audit work is crucial, the person responsible for the audit report must have experience in accounting and auditing work. In a CPA Firm, generally only colleagues who have a degree such as a CPA can sign the audit report. Section 210 PSA No. 4 emphasizes that the audit must be carried out by one or more people who have sufficient technical expertise and training. As the leader who is also responsible for the audit report, the partner needs to ensure that the audit findings meet the minimum quality standards required. DeAngelo (1981) as cited in Agoes and Rahmina (2014) defines audit quality as the possibility of auditors to find and report violations that occur in the client's accounting system. This quality includes gathering evidence needed to provide a fair opinion on the audit report.

The quality of the audit is crucial, especially for the stakeholders. Herawaty (2009) shows that a CPA Firm with high audit quality increases the level of external parties' trust in the company using the audit services through certainty of the figures prepared by management. The audit quality can be seen from the role of auditors who have adequate competence and are independent so that they can provide certainty to the integrity of accounting numbers (Mayangsari, 2003).

The failure of an audit partner to maintain audit quality can have a profound effect on the client and the reputation of the CPA Firm itself. The public trusts the audited financial statements, so failure to maintain audit quality will undermine the credibility of CPA Firms in maintaining trust. Luthfiyati (2018) explained that companies must be looking for CPA Firms with high credibility so as to increase the credibility of the audited financial statements in front of financial statement users. Thus, a CPA Firm's failure to maintain quality causes audit quality to be questioned by users of financial statements. The example is the collapse of the ZhongTianQin Public Accountant Office (ZTQ) in the People's Republic of China. He, Pittman and Rui (2015) found that the failure of ZTQ associates to maintain audit quality in the work of a large client YinGuangXia (YGX) caused a loss of public trust in ZTQ. In such cases, ZTQ associates fail to maintain audit quality such as the main audit partner not signing the audited financial statements and the complete work documents to meet the audit requirements.

Work experience is the number of years the auditor has worked in the field. The longer the auditor's work experience, the more his experience in analyzing the reasonableness of the client's financial statements. Audit Standard 210 states that the auditor must always act as an expert in carrying out audit tasks. In addition, through the Minister of Finance Regulation No. 01 of 2016, the auditor needs to have one thousand hours of audit service experience on historical financial information in the past seven years, with five hundred hours overseeing the audit engagement.

Lack of auditor work experience could cause quite fatal audit results. An auditor for PT Kimia Farma failed to detect a mark-up of almost Rp. 132 billion conducted by clients in the financial statements for December 31, 2001 (Winantyadi \& Waluyo, 2014). In this case, the mistake of PT Kimia Farma's auditors was being late in realizing and reporting irregularities in financial statements. Auditors with sufficient work experience should be able to detect a mark-up of almost Rp. 132 billion and immediately reflect it in the audit report. In addition to work experience, the auditor must also follow auditor's ethics in accordance with the ethical standards set by the Indonesian Institute of Certified Public Accountants (Ikatan Akuntan Publik Indonesia/IAPI). According to the Public Accountant Professional Ethics Code issued by IAPI, public accountants need to fulfill the five basic principles of professional ethics, namely: (a) Integrity, (b) Objectivity, (c) Professional Competency, (d) Confidentiality, and (e) Professional Behavior. 
One way to maintain the auditors' integrity is to be independent in the audit process. Gunawan (2012) defines auditor independence as important so that the work produced can be accounted for. An example of the importance of auditors' independency is Enron in the United States. In that case, Arthur Andersen failed to maintain auditors' independency. Besides providing audit services, Andersen also provided consulting services to Enron, and many of Enron's financial employees previously worked at Arthur Andersen. As a result of the failure, Arthur Andersen's reputation collapsed. Many Andersen branches in various countries were taken over by other CPA Firms and the number of Andersen employees fell from a total of 28,000 to 200 in just 3 years (Mears, 2005).

The component that also influences the auditor is professional competence. According to standard 100.5 (b) of the public accountant's code of ethics according to IAPI, professional competence is defined as professional knowledge and expertise at the level needed to ensure that clients will receive professional services according to the development of practice. This means that auditors need to have the latest knowledge to carry out audits in accordance with the latest standards.

The competency code of ethics indirectly forces auditors to keep abreast of the latest accounting and auditing developments as accounting and auditing standards may change according to the latest accounting developments. Auditors can attend seminars on the latest regulations that IAPI regularly holds or subscribe to accounting and auditing magazines that provide auditors with information about the development of existing knowledge. Specifically, Minister of Finance Regulation no. 154/PMK.01/2017 requires public accountant permit holders to attend ongoing professional training, at least 40 credit units each year. The regulation shows that the Indonesian government considers auditor competencies seriously that it is obliged to attend seminars for maintaining licenses.

While clients use the company's audited financial statement for various purposes, a CPA Firm also has the accountability to other parties for the audit report. Krissindiastuti and Rasmini (2016) states that the going concern opinion would have impacted on the decline of share prices, mistrust of investors and creditors. The case of Royal Bank of Scotland vs Bannerman, Johnstone Maclay, is a well-known case that shows the important role of auditors in investor decisions. The investor succeeded in suing the auditor through the claim that the audited financial statements did not show the true financial position. Heald (2018) even wrote that due to the Bannerman case, an audit company in the United Kingdom included a Bannerman clause to minimize auditor accountability. So the client demanded the audit report produced by the CPA Firm show fairness so that the client could use the report for their needs. On the other hand, auditors also need the freedom to report financial statements as they are. Nanda (2015) writes that in the long run the relationship between the auditor and the client could cause the auditor to fulfill the wishes of the client thereby compromising the need to follow professional standards.

The research problem of this study is to analyze the effect of independence, work experience, competence and accountability of auditors on audit quality. For academicians, this research could be developed and used as a reference, and could also contribute to the development of auditing, especially regarding audit quality. The benefit for a CPA Firm is that companies could use this research as an analytical tool to improve the quality of services provided. Leaders of the CPA Firm also could receive input on the level of staff awareness of the code of ethics and its effect on audit quality.

\section{LITRATURE REVIEW}

Several studies have examined the relationship of independence, professional competence, work experience and audit accountability to audit quality. The findings of the research are varied, Wiratama and Budiartha (2015) found that independence, professional competence, work experience and audit accountability had a positive effect on audit quality. Agustin (2013) also has the same results with variables of auditors' independency, work experience and accountability. Meanwhile, Ningrum and Wedari (2017) found that professional competence did not affect audit quality. A summary of the literature review can be seen in table 1: 
Table 1: Previous Studies

\begin{tabular}{|c|c|c|c|c|}
\hline No & Reseracher(s) & Title & Variables & Results \\
\hline 1 & $\begin{array}{l}\text { William } \\
\text { Jefferson } \\
\text { Wiratama \& } \\
\text { Ketut } \\
\text { Budiartha } \\
(2015)\end{array}$ & $\begin{array}{l}\text { Influence of Independence, } \\
\text { Work experience, } \\
\text { Professional Competence and } \\
\text { Accountability towards } \\
\text { Audit Quality }\end{array}$ & $\begin{array}{l}\text { Dependent: } \\
\text { 1. Audit quality } \\
\text { Independent: } \\
\text { 1. Work experience } \\
\text { 2. Independence } \\
\text { 3. Due Professional Care } \\
\text { 4. Accountability }\end{array}$ & $\begin{array}{l}\text { Independence, work } \\
\text { experience, competence } \\
\text { professional and } \\
\text { accountability have a } \\
\text { positive effect on audit } \\
\text { quality }\end{array}$ \\
\hline 2 & $\begin{array}{l}\text { Reni } \\
\text { Febrianti } \\
\text { (2014) }\end{array}$ & $\begin{array}{l}\text { Influence of Independence, } \\
\text { Professional Competence and } \\
\text { Accountability for Audit } \\
\text { Quality }\end{array}$ & $\begin{array}{l}\text { Dependent: } \\
\text { 1. Audit quality } \\
\text { Independent: } \\
\text { 1. Independence } \\
\text { 2. Professional competence } \\
\text { 3. Accountability }\end{array}$ & $\begin{array}{l}\text { 1. Independence and } \\
\text { accountability have no } \\
\text { significant positive effect } \\
\text { on audit quality } \\
\text { 2. Professional competence } \\
\text { has a significant positive } \\
\text { effect on audit quality }\end{array}$ \\
\hline 3 & $\begin{array}{l}\text { Muhammad } \\
\text { Alifzuda } \\
\text { Burhanudin \& } \\
\text { Diana } \\
\text { Rahmawati } \\
\text { (2017) } \\
\end{array}$ & $\begin{array}{l}\text { The Effect of Auditor } \\
\text { Accountability and } \\
\text { Independence on Audit } \\
\text { Quality at CPA FIRM } \\
\text { in Yogyakarta }\end{array}$ & $\begin{array}{l}\text { Dependent: } \\
\text { 1. Audit Quality } \\
\text { Independent: } \\
\text { 1. Accountability } \\
\text { 2. Independence }\end{array}$ & $\begin{array}{l}\text { Independence and } \\
\text { Accountability } \\
\text { significant positive effect } \\
\text { on audit quality }\end{array}$ \\
\hline 4 & $\begin{array}{l}\text { Aulia Agustin } \\
\text { (2013) }\end{array}$ & $\begin{array}{l}\text { Effect of Auditor's } \\
\text { Experience, Independence and } \\
\text { Professional Competence on } \\
\text { the Audit Quality of financial } \\
\text { statements } \\
\text { government (Empirical Study } \\
\text { on BPK - RI Provinsi Riau }\end{array}$ & $\begin{array}{l}\text { Dependent: } \\
\text { 1. Audit Quality } \\
\text { Independent: } \\
\text { 1. Work experience } \\
\text { 2. Independence } \\
\text { 3. Professional competence }\end{array}$ & $\begin{array}{l}\text { Work experience, } \\
\text { Independence and } \\
\text { Professional competence } \\
\text { has a positive influence on } \\
\text { audit quality. }\end{array}$ \\
\hline 5 & $\begin{array}{l}\text { Putri Fitrika } \\
\text { Imansari \& } \\
\text { Abdul Halim, } \\
\text { Retno } \\
\text { Wulandari } \\
\text { (2013) }\end{array}$ & $\begin{array}{l}\text { Effect of Auditor Competence, } \\
\text { Independence, Experience and } \\
\text { Ethics on Audit Quality } \\
\text { (Empirical Study on CPA } \\
\text { FIRM in Malang City) }\end{array}$ & $\begin{array}{l}\text { Dependent: } \\
\text { 1. Audit Quality } \\
\text { Independent: } \\
\text { 1. Competence } \\
\text { 2. Independence } \\
\text { 3. Experience } \\
\text { 4. Auditor Ethics } \\
\end{array}$ & $\begin{array}{l}\text { Auditor Competency, } \\
\text { Independence, Experience } \\
\text { and Ethics significantly } \\
\text { influence audit quality }\end{array}$ \\
\hline 6 & $\begin{array}{l}\text { Gita Sulistya } \\
\text { Ningrum } \\
\text { \& Linda } \\
\text { Kusumaning } \\
\text { Wedari (2017) }\end{array}$ & $\begin{array}{l}\text { Impact of Auditor's Work } \\
\text { Experience, Independence, } \\
\text { Objectivity, Integrity, } \\
\text { Competency and } \\
\text { Accountability on Audit } \\
\text { Quality }\end{array}$ & $\begin{array}{l}\text { Dependent: } \\
\text { 1. Audit Quality } \\
\text { Independent: } \\
\text { 1. Work experience, 2. } \\
\text { Independence, 3. Integrity. } \\
\text { 4. Objectivity, 5. } \\
\text { Competence, } 6 \text {. } \\
\text { Accountability }\end{array}$ & $\begin{array}{l}\text { 1. Independence, Work } \\
\text { Experience, } \\
\text { Accountability and } \\
\text { Objectivity } \\
\text { Have a significant effect on } \\
\text { audit quality } \\
\text { 2. Competence and } \\
\text { Integrity does not affect } \\
\text { quality }\end{array}$ \\
\hline 7 & $\begin{array}{l}\text { I Made Dwi } \\
\text { Kresna Ratha } \\
\text { \& I Wayan } \\
\text { Ramantha } \\
\text { (2015) }\end{array}$ & $\begin{array}{l}\text { Effects of Professional } \\
\text { Competence, Accountability, } \\
\text { Audit Complexity and Time } \\
\text { Budget Pressure on audit } \\
\text { quality }\end{array}$ & $\begin{array}{l}\text { Dependent: } \\
\text { 1. Audit Quality } \\
\text { Independent: } \\
\text { 1. Professional competence } \\
\text { 2. Accountability }\end{array}$ & $\begin{array}{l}\text { 1. Professional competence } \\
\text { and } \\
\text { Accountability has a } \\
\text { positive impact on audit } \\
\text { quality. } \\
\text { 2. Complexity and Time } \\
\text { Budget Pressure has a } \\
\text { negative impact on quality }\end{array}$ \\
\hline
\end{tabular}




\section{Research Framework}

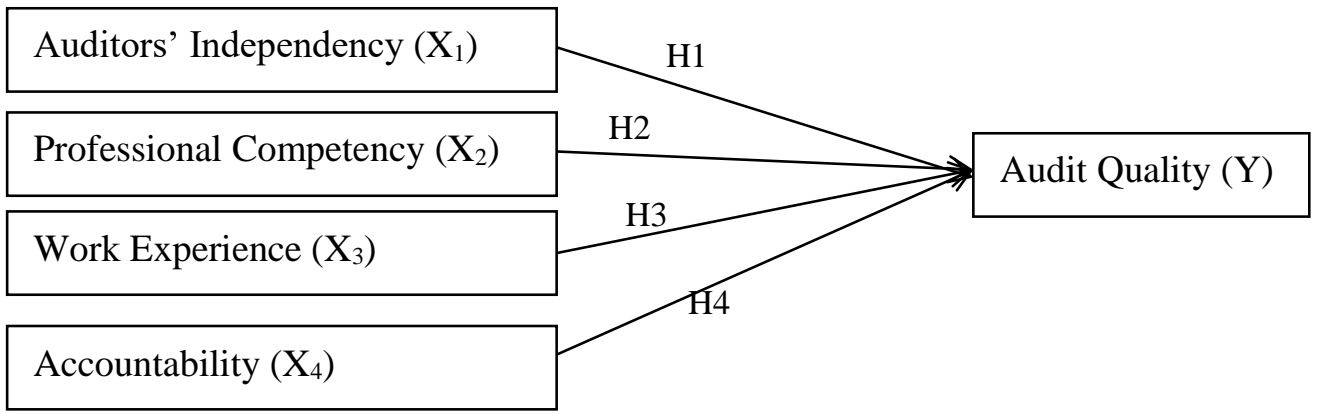

Figure 1: Conceptual Framework

\section{Hypothesis}

\section{Auditors' independency has a positive effect on audit quality}

As one of the fundamental Code of Ethics that must be obeyed by the auditor, auditors' independency ensures that the auditor is not influenced by the client in carrying out audit tasks. According to Wiratama and Budiartha (2015), independence has a significant positive effect on audit quality. They found that the auditors' independency on audit quality is closely related to the second general standard of SPAP (2001), namely that the auditors' independency of a CPA Firm must be maintained by the auditor in all matters relating to audit engagement. The purpose of maintaining such independence is that the audit results represent the actual state of the financial statements.

These findings are consistent with research conducted by Ningrum and Wedari (2017). They found that independence is the objective focus of the auditor's work so that audit quality is influenced by independence. The purpose of this focus, stems from the assumption that independence is an attribute that protects the integrity of financial statements. Research with the same conclusion was also carried out by Agustin (2013), and Burhanudin and Rahmawati (2017). On the other hand, Nandari and Latrini (2015) found that independence did not have a positive influence on audit quality. They found that the difficulty in maintaining auditors' independency was due to lack of work experience and long-standing relationships with clients. The research also found that the auditors' independency must be built from the auditors' awareness and not derived from a CPA Firm. Based on the previous studies, the research hypothesis $\left(\mathrm{H}_{1}\right)$ is that independence has a positive effect on audit quality.

\section{Professional competency has a positive effect on audit quality}

Saripudin and Herawaty (2012) define professional competence as professional skills that are careful and thorough in carrying out audit tasks. Auditors have the accuracy to detect irregularities that occur and the possibility of financial statements does not properly represent the actual financial position of the company. Existing professional skills also require auditors to remain prepared to be skeptical of supporting documents on items in the financial statements. In accordance with the standards of Section 130.1 of the Code of Ethics issued by IAPI, each auditor is required to maintain professional knowledge at a level that ensures that the client will receive competent services in accordance with professional standards. According to research conducted by Febrianti (2014), professional competence has a significant positive effect on audit quality. The conclusion of this finding is in accordance with research conducted by Wiratama and Budiartha (2015) who also concluded that professional competence is a positive influence on quality. The more auditors are prepared to be careful and maintain quality as demanded, the better the quality of the audit because the auditor has met the minimum IAPI standards. Research conducted by Kresna and Ramantha (2015) also has conclusions in line with the two previous studies. Based on this research, the hypothesis $\mathrm{H}_{2}$ is formulated as: the professional competence has a positive influence on audit quality.

\section{Work experience has a positive effect on audit quality}

Work experience is a learning process and the development of behavioral potential increases from both formal and non-formal education. Work experience can also be interpreted as a process that brings 
someone to a higher level of behavior (Kovinna \& Betri, 2012). The longer an auditor has a career in the audit field, the more types of clients are handled so that the auditor should have a lot of experience in resolving various kinds of client situations. According to Wiratama and Budiartha (2015), and Ningrum and Wedari (2017), work experience has a significant positive effect on audit quality. This is due to a better understanding in the auditing of financial statements. Based on the previous studies, the hypothesis $\left(\mathrm{H}_{3}\right)$ : there is a positive relationship between work experience and the quality of audits produced.

\section{Accountability has a positive effect on audit quality}

Research conducted by Wiratama and Budiartha (2015) found that accountability has a positive influence on audit quality through awareness of the large responsibilities assumed by the community and profession. The findings of this study are consistent with the results of research by Burhanudin and Rahmawati (2017) who found that accountability encourages auditors to improve audit quality in accordance with stakeholder expectations. Research conducted by Ratha and Ramantha (2015) also supports the positive influence of accountability on audit quality. Motivation, devotion to the profession, and complex social obligations are contributing factors. In contrast, Nandari and Latrini (2015) found accountability does not have a positive influence on audit quality. The study found that, in reality, auditors can still control the complexity of the work so that accountability is not material to the complexity of the work they have. The results of the study are also in accordance with research conducted by Febrianti (2014). Lack of efficiency and effectiveness is the cause of the negative relationship between accountability and audit quality. Based on these studies, this research hypothesis $\left(\mathrm{H}_{4}\right)$ is: there is a positive relationship between accountability and audit quality.

\section{METHOD}

Pilot testing was carried out at the CPA Firm DBSDA Bandung branch and was carried out on July 24, 2019 during the working day. Testing was carried out by distributing existing questionnaires directly to existing staff and colleagues. Subsequent tests were carried out by sending e-mails to four other CPA Firm DBSDA branches in Bekasi, Central Jakarta, South Jakarta and West Jakarta.

The determined population was auditors working in 5 DBSDA CPA Firm branches in Bandung, Bekasi, Central Jakarta, South Jakarta and West Jakarta with the population of 77 CPA Firms. Respondents who gave responses in this study were 38 people. Existing respondents included juniors, seniors, audit managers and audit partners. Table 2 shows the respondents from the population of each CPA Firm.

Table 2: Respondents from Population

\begin{tabular}{|l|c|c|}
\hline Branch of CPA FIRM DBSDA & Respondents & Population \\
\hline Bandung & 11 & 16 \\
\hline Jakarta Pusat & 8 & 20 \\
\hline Jakarta Selatan & 6 & 15 \\
\hline Jakarta Barat & 6 & 14 \\
\hline Malang & 7 & 12 \\
\hline
\end{tabular}

The sampling technique in this study was purposive sampling. The sampling criteria are that the auditor has worked for at least one year at CPA Firm and has graduated with a Bachelor Degree in Accounting.

Hypothesis testing is done to see the effect of independence, professional competence, work experiences and auditor accountability on audit quality using multiple regression methods. Respondents were asked to provide opinions on closed questions, ranging from strongly disagree to strongly agree. Table 3 shows the values for each answer choice. 
Table 3: Questionnaire Values

\begin{tabular}{|l|c|}
\hline Answer & Value \\
\hline Strongly Disagree & 1 \\
\hline Disagree & 2 \\
\hline Neutral & 3 \\
\hline Agree & 4 \\
\hline Strongly Agree & 5 \\
\hline
\end{tabular}

The questionnaire used from Lestari (2017), Febryianti (2014), Musthofa (2018), and Priyambodo (2014):

Independence (Lestari, 2107):

1. In carrying out audit tasks, I get pressure from clients.

2. In carrying out non-audit services, auditors act as corporate accountants and accountants must not express opinions.

3. Providing non-audit services to the same client influences auditor independence.

Professional Competence (Febriyanti, 2104):

1. In carrying out the work the auditor works carefully and has skills in auditing financial statements.

2. Auditors have determination, sincerity and are energetic.

3. The auditor has the technical ability to carry out audit procedures and carry out them carefully.

4. Auditors need not be aware of fraud that occurs in auditing financial statements.

5. In carrying out the work, the auditor is always alert to the significant risks that can affect the objectivity of the audit.

Work experience (Priyambodo, 2014):

1. The longer I become an auditor, the more I understand how to deal with entities / objects of examination in obtaining the data and information needed.

2. The longer I become an auditor, the more I can find out relevant information to take into consideration in making decisions.

3. The longer I work as an auditor, the more I can detect errors made by the inspection object.

4. The longer I become an auditor, the easier it is for me to find the cause of error and can provide recommendations to eliminate or minimize the cause.

5. The number of inspection tasks that I do requires accuracy and accuracy in completing them.

6. The many tasks faced provide an opportunity to learn from the failures and successes that I have experienced.

7. The number of tasks received can spur me to complete work quickly and without a buildup of tasks.

Accountability (Musthofa, 2018):

1. I am enthusiastic about the work I do.

2. I prioritize personal interest more than professional relationships in carrying out this profession.

3. Auditors have an important role for the community and government.

Audit Quality (Lestari, 2017), (Febryianti, 2014), (Musthofa, 2018) and (Priyambodo (2014):

1. I guarantee that my audit findings are accurate. I can find the slightest error/deviation that exists.

2. The recommendations that I give can correct the causes of errors/deviations that exist.

3. My audit report can be understood by the client.

4. The audit that I do can reduce the level of errors/deviations that have occurred.

5. The results of my audit can be followed up by the client.

6. I continue to monitor the follow-up of audit results. 


\section{RESULT AND DISCUSSION}

The analysis of the influence and magnitude of the functional relationship of independence with audit quality

The analysis can be seen in table 4 below:

Table 4: Summary of Hypothesis Testing

\begin{tabular}{|l|r|r|r|r|}
\hline & $\mathbf{X}_{\mathbf{1}}$ to Y & $\mathbf{X}_{\mathbf{2}}$ to Y & $\mathbf{X}_{\mathbf{3}}$ to Y & $\mathbf{X}_{\mathbf{4}}$ to Y \\
\hline Unstd. Coeff. (Constant) & 1.680 & 1,246 & 1,515 & 1,638 \\
\hline Unstd. Coeff. Independency & 0.390 & 0,488 & 0,407 & 0,428 \\
\hline Regression (Sig.) & 0.018 & 0,002 & 0,011 & 0,009 \\
\hline R Square & 0.145 & 0,239 & 0,165 & 0,176 \\
\hline
\end{tabular}

From the regression equation above, it can be interpreted that every increase of one unit of auditors' independency is 0.390 , it will be followed by an increase in audit quality by 1,680 . Thus, any increase in changes or additions to independence will be followed by improvement in quality.

Then, to ensure that the two variables depend on each other, it is necessary to check the significance of the equation using the variant analysis (ANOVA). Based on the results in table 4, the significance value is 0.018 . This implies that auditors' independency contributes significantly to audit quality. So, the research model can be used in this study, and it can be concluded that the higher the independence, the higher the audit quality.

Furthermore, to find out the relationship between the independence and the audit quality, correlation analysis is used. The results show the correlation coefficient ( $r$ ) of 0.381 with a coefficient of determination $\left(\mathrm{R}^{2}\right)$ of 0.145 . Thus it can be said that the magnitude of the relationship between auditors' independency and audit quality is $14.5 \%$, and $85.5 \%$ would be influenced by other factors. Based on the value of the correlation coefficient shows a low and positive relationship, this means that there is a direct relationship between independence and audit quality. If the value of independence increases, the value of audit quality will also increase significantly. Therefore, the first hypothesis $\left(\mathrm{H}_{1}\right)$ is accepted.

\section{Analysis of Influence and Magnitude of Functional Relationship of Work Experience with Audit Quality}

Based on the results of the regression calculation of the work experience variable to the audit quality variable, the value of $a=1,246$ and $b=0,488$. From the regression equation above, it can be interpreted that each increase of one unit of auditors' independency is 0.488 , it will be followed by an increase in audit quality of 1.246. Thus, any increase in changes or additions to work experience will also be followed by an increase in audit quality.

Based on the ANOVA result in table 4, a significance value of 0.002 is obtained, with a value of 0.000 less than $\alpha=0.05$. This implies that a simple linear regression model can be used to predict the level of audit quality that is influenced by work experience. This shows that there is a relationship between work experience variables and audit quality variables, so work experience variables do affect audit quality. So the research model can be used in this study, and it can be concluded that higher the work experience, higher the audit quality.

Furthermore, to find out the close functional relationship between work experience and audit quality, correlation analysis is used. The results showed that work experience and audit quality have a correlation coefficient ( $r$ ) of 0.489 with a coefficient of determination $\left(R^{2}\right)$ of 0.239 . Thus it can be said the magnitude of the contribution of the relationship of work experience with audit quality is $23.9 \%$, while $76.1 \%$ would be influenced by other factors. Based on the correlation coefficient value, it shows a strong and positive relationship, this means that there is a direct relationship between work experience and audit quality. If the value of work experience increases, the value of audit quality will also increase significantly. So, it can be concluded that the second hypothesis $\left(\mathrm{H}_{2}\right)$ in this study, namely that there is 
a significant influence between work experience on audit quality is accepted.

\section{Analysis of the Effect and Magnitude of the Functional Relationship of Professional Competence with Audit Quality}

Based on the results of the regression calculation of the variable professional competence to the audit quality variable obtained value $a=1.515$ and $b=0.407$. It can be interpreted that each increase of one unit of professional competence is 0.407 , it will be followed by an increase in audit quality by 1,515 .

Based on the results of ANOVA in table 4, a significance value of 0.011 is less than $\alpha=0.05$. This implies that a simple linear regression model can be used to predict the level of audit quality that is influenced by professional competence. So it can be said that professional competence contributes significantly to audit quality. So the research model can be used in this study, and the higher the professional competence, the higher the audit quality.

Furthermore, to determine the close functional relationship between the variables of professional competence and audit quality variables correlation analysis is used. The results of the calculation of correlation analysis show that both variables have a correlation coefficient ( $\mathrm{r}$ ) of 0.408 with a coefficient of determination $\left(\mathrm{R}^{2}\right)$ of 0.165 . Thus it can be said the magnitude of the contribution of the relationship given professional competence with audit quality is $16.5 \%$, while $83.5 \%$ is influenced by other factors. Based on the correlation, coefficient value shows a small and positive relationship; this means that there is a direct relationship between professional competence and audit quality. If the value of professional competence rises, the value of audit quality will also increase significantly. This means that there is a significant influence between auditor's competencies on audit quality. So, it can be concluded that the third hypothesis $\left(\mathrm{H}_{3}\right)$ in this study is accepted.

\section{Analysis of the Effect and Magnitude of the Functional Relationship of Accountability with Audit Quality}

Based on the results of the regression calculation of the accountability variable to the audit quality variable, the value of $a=1.638$ and $b=0.428$. From the regression equation above it can be interpreted that for each increase of one unit of accountability is 0.428 , it will be followed by an increase in audit quality by 1,638 . As such, any incremental increase in accountability will be followed by an increase in audit quality.

Based on ANOVA results in table 4, it implies that a simple linear regression model can be used to predict the level of audit quality that is influenced by accountability. So it can be said that the accountability variable contributes significantly to quality. This shows that there is a relationship between the accountability variable with the audit quality variable, so the accountability variable does affect the audit quality. It meas that the higher the accountability, the higher the audit quality.

Furthermore, to find out the close functional relationship between the accountability and the audit quality, correlation analysis is used. The results of the calculation of correlation analysis show that both variables have a correlation coefficient $(\mathrm{r})$ of 0.419 with a coefficient of determination $\left(\mathrm{R}^{2}\right)$ of 0.176 . Thus it can be said the magnitude of the contribution of the relationship given accountability with audit quality is $17.6 \%$, while $82.4 \%$ would be influenced by other factors. Based on the provisions of the correlation coefficient value shows a small and positive relationship, this means that there is a direct relationship between accountability and audit quality. If the value of accountability increases, the value of audit quality will increase significantly. Based on the results of data processing in table 4, there is a significant influence between accountability on audit quality. So, it can be concluded that the fourth hypothesis $\left(\mathrm{H}_{4}\right)$ is accepted. 


\section{CONCLUSION}

The conclusion of this research is as follows:

1. The auditor's work experience in conducting an audit has a positive and significant effect on audit quality in CPA Firm DBSDA, so the more experienced an auditor, the better the quality of the audit he does. This is consistent with research conducted by Wiratama and Budiartha (2015), and Agustin (2013) who found that auditor work experience has a positive influence on audit quality.

2. Auditors' Independence has a positive and significant effect on audit quality so it can be concluded that if the auditor has a good independence behavior in CPA Firm and is not influenced by other parties, then the resulting audit quality will be good too. This is consistent with Burhanuddin and Rahmawati (2017), and Ningrum and Wedari (2017) who also found that audit independence has a positive effect on audit quality.

3. Professional competence has a positive and significant influence on audit quality. In other words, the audit quality variable is influenced by professional competence so it can be concluded that auditors who have high competence can produce high audit quality. The conclusion is also in accordance with Wiratama and Budiartha (2015), and Ratha and Ramantha (2015) who found that professional competence has a positive influence on audit quality.

4. Accountability has a positive and significant effect on audit quality so it can be concluded that high auditor accountability will result in high audit quality. These findings are consistent with Ningrum and Wedari (2017), and Wiratama and Budiartha (2015) who found that accountability has a positive and significant effect on audit quality.

The results of this study show that the auditor's experience and knowledge are positive for audit quality. These results have implications for the auditor assignments in conducting audits. An audit should be carried out by an experienced auditor and deemed to have adequate knowledge. This can be done by a senior auditor or partner. Audits can also be given to junior auditors but must be accompanied by a minimum of senior auditors. This pattern of assignment is an effort to maintain audit quality so that the credibility of audit results in the eyes of users of financial statement information can be maintained. Moreover, the auditor should ensure that auditor independence cannot be influenced by pressure from clients due to existing relationships. One way to meet these needs is to fill in the independence form available from CPA Firm. For further research, the research population can be expanded by increasing the number of respondents working at CPA Firm in other cities, or using other larger research subjects such as CPA Firm "Big Four" or "Big Four" partners, or CPA Firm "Non Big Four" affiliated with foreign CPA Firm.

\section{REFERENCES}

Agoes, S. \& Rahmina, L.Y (2014). Influence of Auditor Independence, Audit Tenure and Audit Feeon Audit Quality of Members of Capital Market Accountant Forum in Indonesia. Social and Behavioural Sciences 164 (2014).

Agustin, A. (2013). Pengaruh Pengalaman, Independensi dan Kompetensi Profesional Auditor terhadap Kualitas Audit Laporan Keuangan Pemerintah (Studi Empiris pada BPK - RI Perwakilan Provinsi Riau). Fakultas Ekonomi Universitas Negeri Padang, Vol. 01, No. 01.

Arens, A.A., Elder, R.J., Beasley, M.S. (2011). Auditing dan Pelayanan Verifikasi: Pendekatan Terpadu, Edisi kesembilan, Jakarta: Indeks.

Ardani, S.V. (2017). Pengaruh Tenure Audit, Rotasi Audit, Audit Fee terhadap Kualitas Audit dengan Komite Audit sebagai Variabel Moderasi (Studi Pada Perusahaan Sektor Keuangan yang terdaftar di BEI Tahun 2010 - 2014). Jurnal Akuntansi, Vol 6, No. 1.

Burhanudin, M.A. \& Rahmawati, D. (2017). Pengaruh Akuntabilitas dan Independensi Auditor terhadap Kualitas Audit pada Kantor Akuntan Publik di Yogyakarta. Jurnal Profita, Edisi 6, 2017.

Chambers, A.E. \& Penman, S.H. (1984). Timeliness of Reporting and the Stock-Price Reaction to Earnings Accouncements. Journal of Accounting Research, Vol. 22, No. 1.

Febriyanti, R. (2014). Pengaruh Independensi, Due Professional Care dan Akuntabilitas terhadap Kualitas Audit (Studi Empiris Pada Kantor Akuntan Publik di Kota Padang dan Pekanbaru), Universitas Negeri Padang. 
Gunawan, L.D. (2012). Pengaruh Tingkat Independensi, Kompetensi, Obyektifitas dan Integritas Auditor terhadap Kualitas Audit yang dihasilkan Kantor Akuntan Publik di Surabaya. Jurnal Ilmiah Mahasiswa Akuntansi, Vol. 01, No. 04.

He, X., Pittman, J., Rui, O., (2016). Reputational Implications for Partners after a Major Audit Failure: Evidence from China. Journal of Business Ethics, Vol. No. 4.

Heald, D. (2018). Transparency - generated trust: The Problematic Theorization of Public Audit. Financial Accountability \& Management No. 34.

Herawaty, V. (2009) Peran Praktek Corporate Governance Sebagai Moderating Variabel dari pengaruh Earnings Management Terhadap Nilai Perusahaan, Jurnal Akuntansi dan Keuangan, Vol. 10, No.2.

Imansari, P.F., Wulandari, A.H.R (2013). Pengaruh Kompetensi, Independensi, Pengalaman dan Etika Auditor terhadap Kualitas Audit (Studi Empiris pada Kantor Akuntan Publik di Kota Malang). Jurnal Riset Mahasiswa Akuntansi, Vol 4 No. 1.

Kovinna. F \& Betri (2012). Pengaruh Independensi, Pengalaman Kerja, Kompetensi dan Etika Auditor terhadap Kualitas Audit (Studi Kasus pada Kantor Akuntan Publik di kota Palembang).

Krissindiastuti, M. \& Rasmini, N.K. (2016). Faktor-Faktor yang mempengaruhi Opini Audit Going Concern. E-jurnal Akuntansi Universitas Udayana, Vol. 14 No. 1.

Luthfiyati, B. (2016). Pengaruh Ukuran Perusahaan, Opini Audit, Pergantian Manajemen, Ukuran CPA Firm dan Audit Tenure terhadap Auditor Switching. Journal of Accounting, Vol. 02, No. 02.

Lestari, D.W. (2017). Pengaruh Fee Audit, Independensi, Kompetensi, Etika Auditor dan Tekanan Anggaran Waktu terhadap Kualitas Audit, IAIN Surakarta.

Mayangsari, S. (2003). Pengaruh Keahlian Audit dan Independensi terhadap Pendapat Audit: Sebuah Kuasieksperimen. Jurnal Riset Akuntansi Indonesia (6)1, 1-22.

Mears, M. (2005). Great (but Misplaced Ecpectations): The Scope of the Attorney Client Privilage in the Corporate Setting.

Menteri Keuangan (2017). Peraturan No. 154 tentang Pembinaan dan Pengawasan Akuntan Publik.

Musthofa, M.A. (2018). Pengaruh Independensi, Pengalaman, Akuntabilitas dan Kompetensi terhadap Kualitas Audit (Studi Empiris pada Aparat Inspektorat Eks Karisidenan Surakarta), Universitas Muhammadiyah Surakarta.

Nanda, F. R. (2015). Pengaruh Audit Tenure, Disclosure, Ukuran KAP, Debt Default, Opinion Shopping dan Kondisi Keuangan terhadap Penerimaan Opini Audit Going Concern (Pada Perusahaan Yang Terdaftar Pada Indeks Syariah BEI), Jurnal Ekonomi, Manajemen dan Akuntansi, Vol. 24, No.1.

Nandari, A.W.S \& Latrini, M.Y. (2015). Pengaruh Sikap Skeptis, Independensi, Penerapan Kode Etik dan Akuntabilitas terhadap Kualitas Audit, E-jurnal Akuntansi Universitas Udayana, Vol. 10 No. 01.

Ningrum, G.S. \& Wedari, L.K. (2017). Impact of Auditor's Work Experience, Independence, Objectivity, Integrity, Competency and Accountability on Audit Quality. Journal of Economics \& Business, Vol. 1 No.1.

Priyambodo, D. (2018). Pengaruh Kompetensi, Independensi, Pengalaman kerja dan Akuntabilitas terhadap Kualitas Audit dengan Etika Auditor sebagai Variabel Moderating. Universitas Muhammadiyah Surakarta.

Ratha, I.M.D.K.R \& Ramantha, I.W(2015). Pengaruh Kompetensi Profesional, Akuntabilitas, Kompleksitas Audit dan Time Budget Pressure terhadap Kualitas Audit. E-Jurnal Akuntansi Universitas Udayana, Vol. 13, No.1.

Republik Indonesia (2011). Undang-Undang No. 5 tentang Akuntan Publik.

Saripudin, N \& Herawaty, R. (2012). Pengaruh Independensi, Pengalaman, Due Professional Care dan Akuntabilitas terhadap Kualitas Audit (Survei terhadap Auditor KAP di Jambi dan Palembang. eJurnal Binar Akuntansi Vol.1 No. 1, September 2012.

Sugiyono. (2013). Metode Penelitian Pendidikan Pendekatan Kuantitatif, Kualitatif, dan $R \& D$. Bandung: Alfabeta.

Winantyadi, N. \& Waluyo, I. (2014). Pengaruh Pengalaman Kerja, Keahlian, Situasi Audit dan Etika terhadap Skeptisisme Profesional Auditor (Studi Kasus pada KAP di Provinsi Daerah Istimewa Yogyakarta). Jurnal Nominal, Vol. 03, No. 01. 
Wiratama, W.J. \& Budiartha, K. (2015). Pengaruh Independensi, Pengalaman Kerja, Kompetensi Profesional dan Akuntabilitas terhadap Kualitas Audit, E-jurnal Akuntansi Universitas Udayana, 10.1 . 